ВІСНИК

ОДЕСЬКОГО НАЦІОНАЛЬНОГО МОРСЬКОГО УНІВЕРСИТЕТУ
HERALD

OF THE ODESSA NATIONAL

MARITIME UNIVERSITY № 1 (61), 2020

УДК 629.553

DOI 10.47049/2226-1893-2020-1-7-28

\title{
ОСОБЕННОСТИ ПРОЕКТИРОВАНИЯ МНОГОФУНКЦИОНАЛЬНОГО ВОДОЛАЗНОГО \\ СУДНА-КАТАМАРАНА ПРОЕКТА SDS18 ТИПА «ИГОРЬ ИЛЬИН»
}

Г.В. Егоров

д.т.н., профессор, генеральный директор

Морское инженерное бюро, Украина, Одесса

Д.В. Черников

главный конструктор

Морское инженерное бюро, Украина, Одесса

Аннотация. Выполнен анализ действующего отечественного водолазного флота. Показана необходимость строительства многофункииональных водолазных судов нового поколения с большой открытой палубой со средствами крепления, динамическим позиционированием, шахтой для спуска водолазов и оборудования, размещением спецперсонала. Разработана концееция судна-катамарана, определены основные характеристики. Выполнено сравнение с существующими водолазными судами. Созданы и оптимизированы обводы многофункичионального водолазного судна-катамарана с помощью модельных испытаний в опытовом бассейне и CFD моделирования. Описаны основные функции и оборудование, установленное на судне.

Ключевые слова: спасательное судно, катамаран, многофункииональность, водолазный комплекс, обводы, проектирование, оборудование.

УДК 629.553

DOI 10.47049/2226-1893-2020-1-7-28

\section{ОСОБЛИВОСТІ ПРОЕКТУВАННЯ \\ БАГАТОФУНКЦІОНАЛЬНОГО ВОДОЛАЗНОГО СУДНА-КАТАМАРАНУ ПРОЕКТУ SDS18 ТИПУ «ГГОР ІЛЬЇН»}

\author{
Г.В. Сгоров \\ д.т.н., професор, генеральний директор \\ Морське інженерне бюро, Украӥна, Одеса \\ Д.В. Черніков \\ головний конструктор \\ Морське інженерне бюро, Україна, Одеса
}

() Егоров Г.В., Черников Д.В., 2020 
Анотація. Виконано аналіз діючого вітчизняного водолазного флоту. Показана необхідність будівництва багатофункиіональних водолазних суден нового покоління з великою відкритою палубою із засобами кріплення, динамічним позиџіонуванням, шахтою для спуску водолазів $i$ обладнання, розміщенням спецперсоналу. Розроблено конщепиію суднакатамарану, визначено основні характеристики. Виконано порівняння з існуючими водолазними суднами. Створено $i$ оптимізовано обводи багатофункиіонального водолазного судна-катамарану за допомогою модельних випробувань в дослідному басейні і CFD моделювання. Описано основні функиії та обладнання, встановлене на судні.

Ключові слова: рятувальне судно, катамаран, багатофункиіональність, водолазний комплекс, обводи, проектування, обладнання.

UDC 629.553

DOI 10.47049/2226-1893-2020-1-7-28

\title{
DESIGN FEATURES OF SDS18 MULTIFUNCTIONAL DIVING VESSEL-CATAMARAN OF «IGOR ILYIN» TYPE
}

\author{
G. Yegorov \\ Doctor of Technical Sciences, Professor, General Director \\ Marine Engineering Bureau, Odessa, Ukraine \\ D. Chernikov \\ chief designer \\ Marine Engineering Bureau, Odessa, Ukraine
}

Abstract. The analysis of native diving fleet in operation is executed. $60 \%$ of diving vessels are in operation with exceeded life term, the oldest vessel «Diver-5» is 62 years old. The further operation of old vessels is associated with risk increase of ensuring maritime safety and high cost of funds for their maintenance and repair. Most vessels are outdated.

Necessity of building of new generation multifunctional diving vessels with large open deck with fastening equipment, dynamic positioning, well for divers and equipment, special personnel accommodation is shown. The concept of diving catamaran is developed, basic characteristics are defined. Comparison with existing diving vessels is made. Hull contours of multifunctional diving catamaran vessel by means of model trials in experimental tank and CFD modelling have been created and optimized. Basic functions and equipment installed on the vessel are described.

Keywords: salvage vessel, catamaran, multifunctionality, diving complex, hull contours, design, equipment.

Постановка проблемы. По информации ФГБУ «Морспасслужба» [4] на 2019 год в состав аварийно-спасательного флота входит 41 водолазное судно, средний возраст судов составляет 25 лет (см. таблицу 1). 
ВІСНИК

ОДЕСЬКОГО НАЦІОНАЛЬНОГО МОРСЬКОГО УНІВЕРСИТЕТУ № 1 (61), 2020
HERALD

OF THE ODESSA NATIONAL

MARITIME UNIVERSITY

№ 1 (61), 2020

Срок службы водолазных судов

\begin{tabular}{|c|c|c|}
\hline $\begin{array}{c}\text { Название судна } \\
\text { (проект) }\end{array}$ & $\begin{array}{c}\text { Год } \\
\text { постройки }\end{array}$ & $\begin{array}{c}\text { Возраст судна, } \\
\text { лет } \\
\end{array}$ \\
\hline Игорь Ильин (SDS18)* & 2017 & 2 \\
\hline Стольный град Ярославль (SDS08)* & 2010 & 9 \\
\hline Ростов Великий (SDS08)* & 2011 & 8 \\
\hline Углич (SDS08)* & 2011 & 8 \\
\hline Рыбинск (SDS08)* & 2012 & 7 \\
\hline Капитан Беклимишев & 1985 & 34 \\
\hline Лазурит & 1989 & 30 \\
\hline Атлас (1454) & 1987 & 32 \\
\hline Рубин (1454) & 1982 & 37 \\
\hline Эпрон (1454) & 1983 & 36 \\
\hline Меркурий (151) & 1975 & 44 \\
\hline Дерзкий & 1988 & 31 \\
\hline Выборг & 1967 & 52 \\
\hline Сою3 & 1988 & 31 \\
\hline Водолаз-14 & 1960 & 59 \\
\hline Водолаз-15 & 1960 & 59 \\
\hline Водолаз Кузьминых (А160-ЯР) & 2018 & 1 \\
\hline Валентин Подгорный (1415) & 1992 & 27 \\
\hline Волна (1415) & 1992 & 27 \\
\hline Водолаз Сташков & 2012 & 7 \\
\hline Водолаз Зубченко & 2013 & 6 \\
\hline Водолаз Зюляев & 2013 & 6 \\
\hline Водолаз Грицай & 2013 & 6 \\
\hline Водолаз Денисов & 2010 & 9 \\
\hline Водолаз Печкуров & 2011 & 8 \\
\hline Водолаз Сазонов & 2013 & 6 \\
\hline Водолаз Литвин & 2011 & 8 \\
\hline Водолаз Малеев & 2013 & 6 \\
\hline Водолаз Чебаненко & 2010 & 9 \\
\hline Водолаз-31 & 1986 & 33 \\
\hline Водолаз-32 & 1986 & 33 \\
\hline ВРД-1097 & 1983 & 36 \\
\hline ВРД-1409 & 1989 & 30 \\
\hline Водолаз & 1987 & 32 \\
\hline Сигнал & 1985 & 34 \\
\hline ВРД-1170 & 1984 & 35 \\
\hline ВРД-1505 & 1992 & 27 \\
\hline ВРД-1462 & 1991 & 28 \\
\hline ВРБ-4 & 1982 & 37 \\
\hline ВРД-1025 & 1981 & 38 \\
\hline Водолаз-5 (522) & 1957 & 62 \\
\hline \multicolumn{2}{|l|}{ Средний возраст } & 25 \\
\hline
\end{tabular}


ВІСНИК

ОДЕСЬКОГО НАЦІОНАЛЬНОГО

МОРСЬКОГО УНІВЕРСИТЕТУ № 1 (61), 2020
HERALD

OF THE ODESSA NATIONAL

MARITIME UNIVERSITY № 1 (61), 2020

При этом 60 \% водолазных судов находятся в эксплуатации с превышением нормативного срока службы, самое старшее судно «Водолаз-5» имеет возраст 62 года. Дальнейшая эксплуатация судов такого срока службы сопряжена с увеличением рисков обеспечения безопасности мореплавания, большими затратами средств на их содержание и ремонт. Большинство судов морально устарели.

В связи с указанными выше проблемами, на замену технически устаревшим водолазным судам необходимо обновление водолазного флота.

Целью статьи является обоснование основных характеристик современного многофункционального судна.

Изложение основного материала. Анализ характеристик существующих спасательных судов и фактически выполняемых ими функций, а также современных аналогов показывает, что общей тенденцией является строительство многофункциональных судов с возможностью применения модульного съемного оборудования (и соответственно наличия открытой палубы достаточной площади со средствами крепления), повышение мощности энергетической установки и устройства динамического позиционирования [7].

Следствием этого интереса стала разработка Морским Инженерным Бюро проекта нового многофункционального водолазного суднакатамарана (MBC) SDS18.

1 декабря 2016 г. на навашинской Окской судоверфи состоялась торжественная закладка киля морского водолазного судна-катамарана проекта SDS18 «Игорь Ильин» (см. рисунок 1), спуск состоялся 26 июля 2017 года (см. рисунок 2). 12 октября 2017 года, т.е. меньше, чем за 11 месяцев, головное судно было сдано в эксплуатацию (см. рисунок 3).

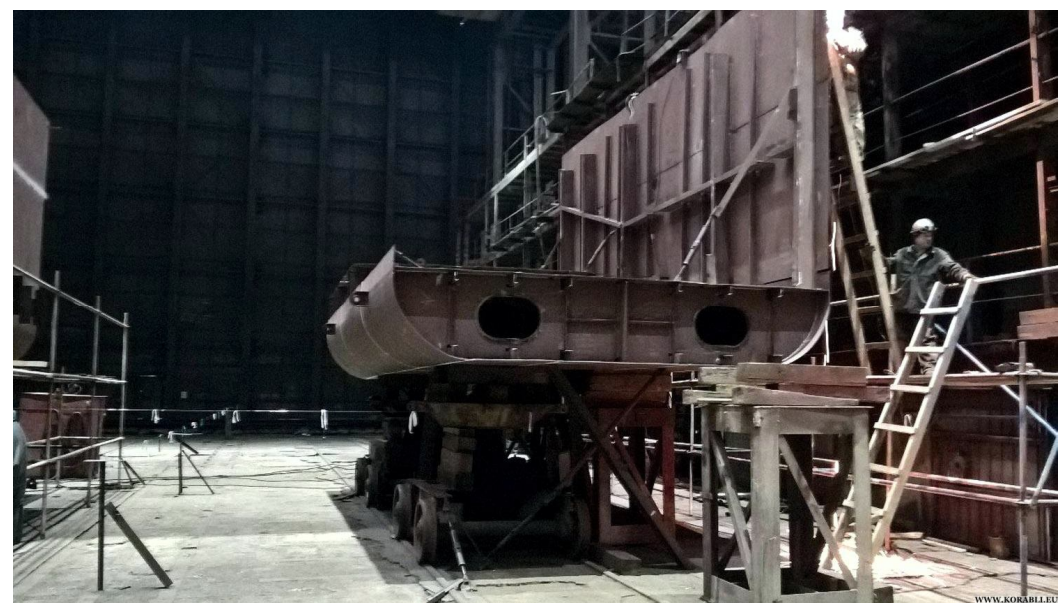

Рис. 1. Процесс постройки МВС «Игорь Ильин» [3] 


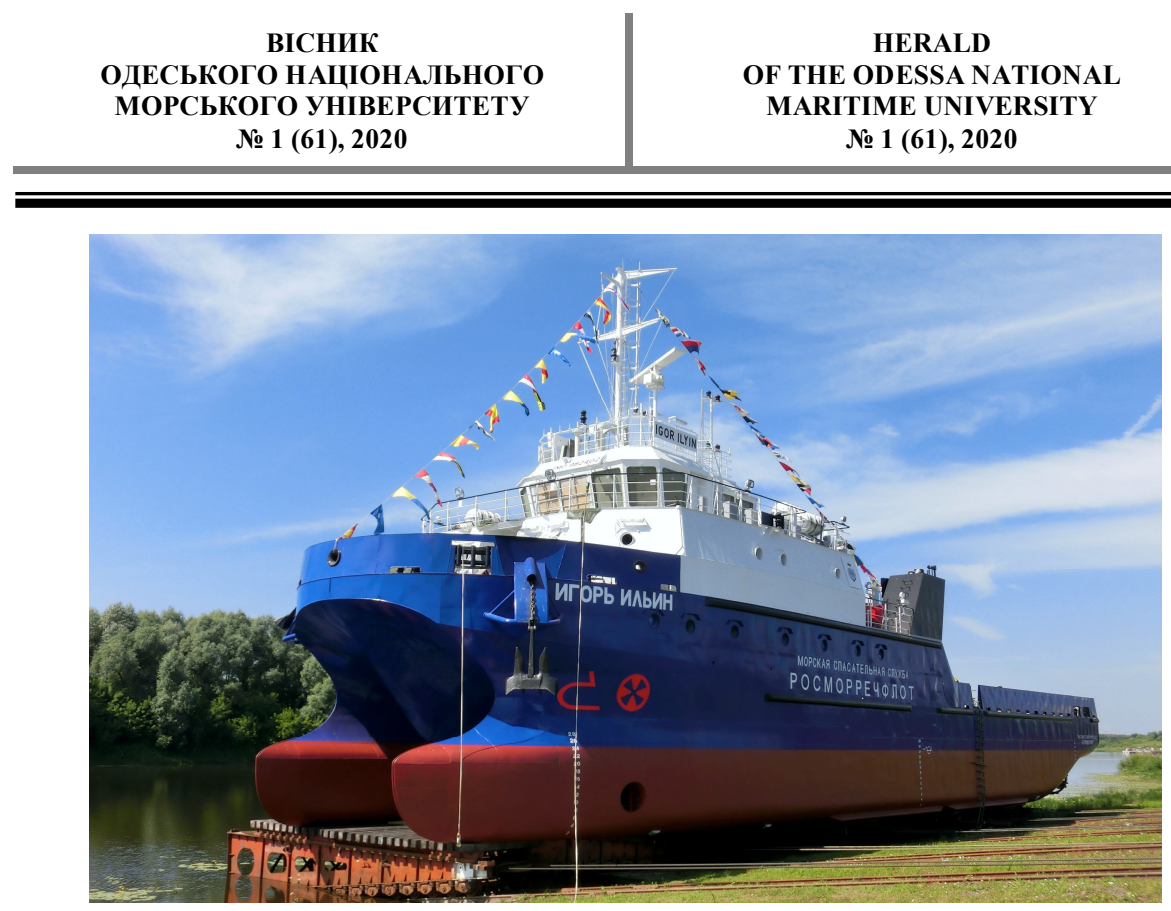

Puс. 2. Головное судно серии проекта SDS18 «Игорь Ильин» на стапеле перед спуском

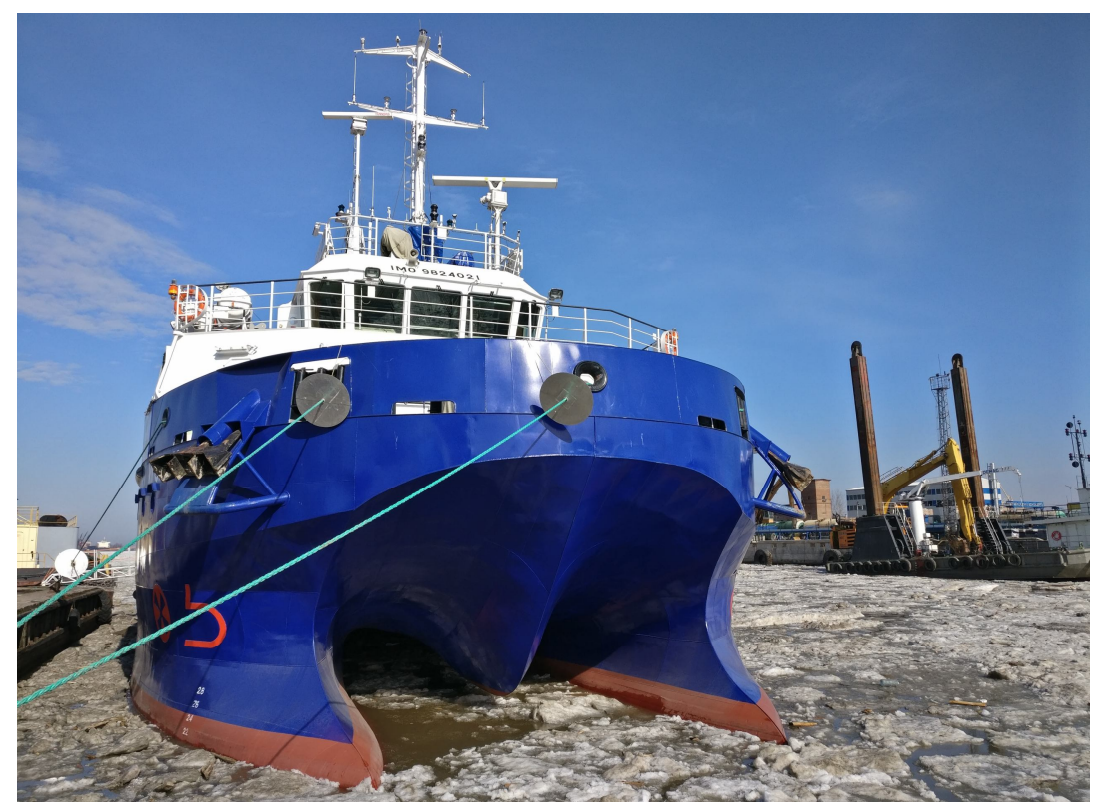

Рис. 3. Головное судно серии проекта SDS18 «Игорь Ильин» у причала

Проект SDS18 морского водолазного судна-катамарана был разработан Морским Инженерным Бюро для ФБУ «Морская спасательная служба Росморречфлота». Заказчиком судна выступила «Государственная транспортная лизинговая компания» (ГТЛК). 
ВІСНИК

ОДЕСЬКОГО НАЦІОНАЛЬНОГО

МОРСЬКОГО УНІВЕРСИТЕТУ

№ 1 (61), 2020
HERALD

OF THE ODESSA NATIONAL

MARITIME UNIVERSITY

№ 1 (61), 2020

Представляет собой (см. общее расположение на рисунке 4) однопалубный стальной двухкорпусный с соединительным мостом катамаран, с надстройкой и рулевой рубкой из алюминиево-магниевых сплавов, с удлиненным баком, с носовым расположением надстройки и рулевой рубки, с открытой грузовой палубой в корме, с двумя полноповоротными винторулевыми колонками (ВРК) и двумя носовыми подруливающими устройствами (ПУ), с расположением машинных отделений в боковых корпусах катамарана. Район плавания - морские районы, соответствующие району плавания R1. По радиооборудованию предполагается эксплуатация в районах A1, A2, A3.
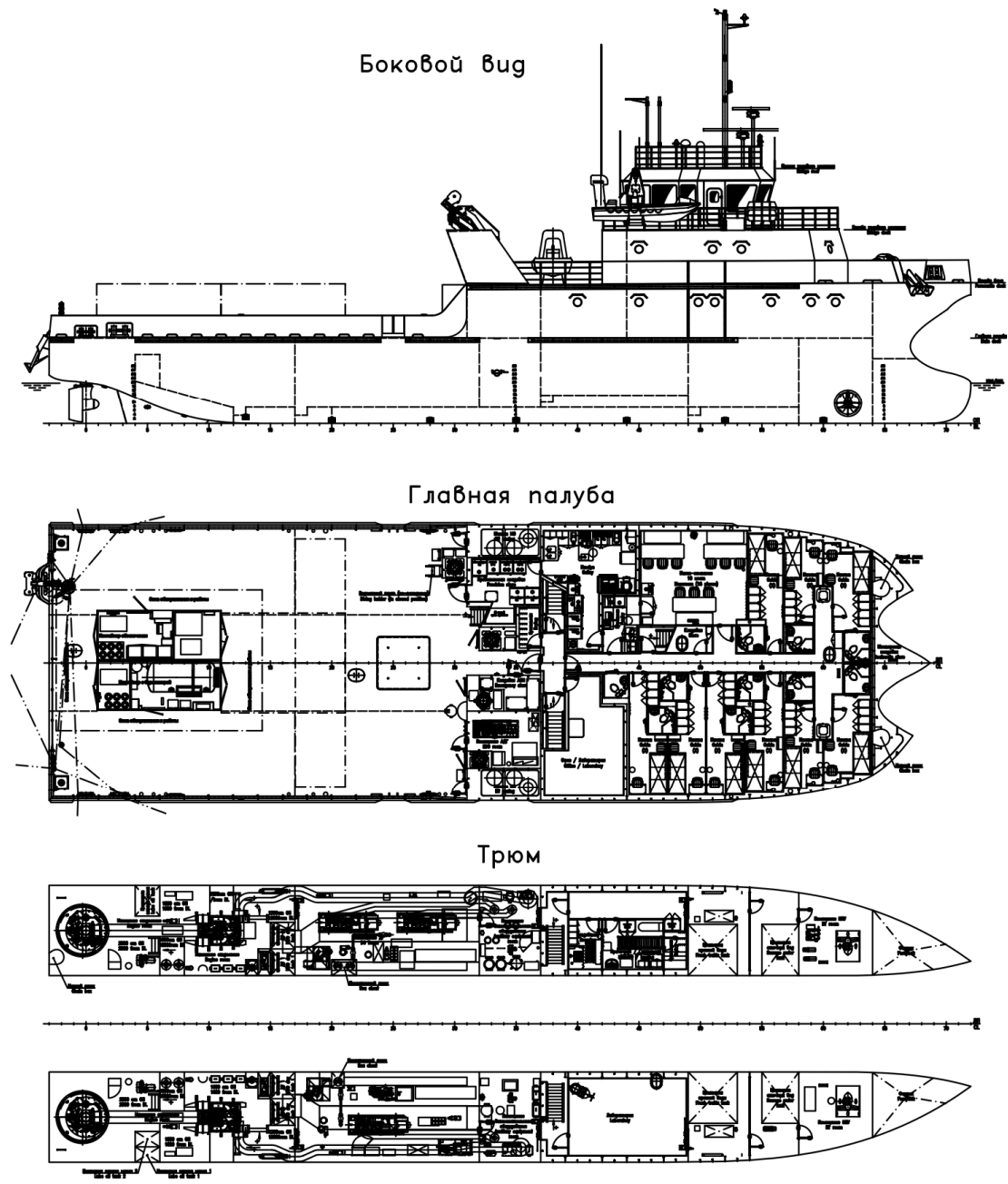

Рис. 4. Общее расположение МBC проекта SDS18 
Функции МBC проекта SDS18:

- обеспечение водолазных и подводно-технических работ на глубинах до 60 метров при волнении моря до 3-х баллов;

- участие в аварийно-спасательных и судоподъемных операциях;

- размещение и обеспечение работы научно-исследовательской партии в объеме установленных технических средств;

- обследование дна акваторий, затонувших объектов, подводной части корпусов судов (кораблей) и гидротехнических сооружений;

- обеспечение эксплуатации малогабаритных телеуправляемых подводных аппаратов при волнении моря до 3 баллов.

- Поэтому при определении главных размерений судна-катамарана и форм корпусов определяющим были следующие факторы:

- выбор длины и общей ширины судна-катамарана обусловлен необходимостью обеспечения открытой рабочей палубы больших размеров для возможности размещения оборудования;

- исходя из ходовых качеств катамарана, ширина каждого корпуса должна быть минимальных размеров, при этом необходимо обеспечить расположение главных механизмов с безопасными зонами для их обслуживания;

- на выбор вертикального клиренса влияет необходимость снижения вероятности ударов волн в нижнюю поверхность соединительного моста, при этом значительная высота борта не должна мешать выполнению основной функции судна - водолазным работам;

- одновременно при выборе общей ширины судна и ширины корпусов необходимо обеспечить оптимальные значения горизонтального клиренса;

- морские условия эксплуатации проекта SDS18 требуют создания судна, которое обладает хорошими мореходными качествами.

Исходя из этого были определены основные размеры (основные характеристики судна см. таблицу 2), при этом судно выполнено с удлиненным баком, простирающимся до мидель-шпангоута, что обеспечило высокий надводный борт в носовой части и низкий надводный борт в районе рабочей площадки для спуска водолазов.

Судно представляет собой катамаран с симметрично расположенными корпусами, объединенными в надводной части. Носовые оконечности корпусов имеют форму форштевня, характерную для бульбообразных обводов, и заостренные ватерлинии. В надводной части между корпусами размещен нависающий обтекатель с заостренным форштевнем в ДП. В носовой части форштевень смещен в сторону к ДП. Кормовые оконечности транцевые, приспособленные для установки полноповоротных ВРК, имеют упрощенную форму днища, образованную прямыми ватерлиниями и скег-стабилизатор перед ВРК (см. теоретические обводы судна на рисунке 5). 
ВІСНИК

ОДЕСЬКОГО НАЦІОНАЛЬНОГО

МОРСЬКОГО УНІВЕРСИТЕТУ

№ 1 (61), 2020
HERALD

OF THE ODESSA NATIONAL

MARITIME UNIVERSITY

\begin{tabular}{c}
2 \\
\multirow{2}{*}{} \\
0 \\
0 \\
0
\end{tabular}

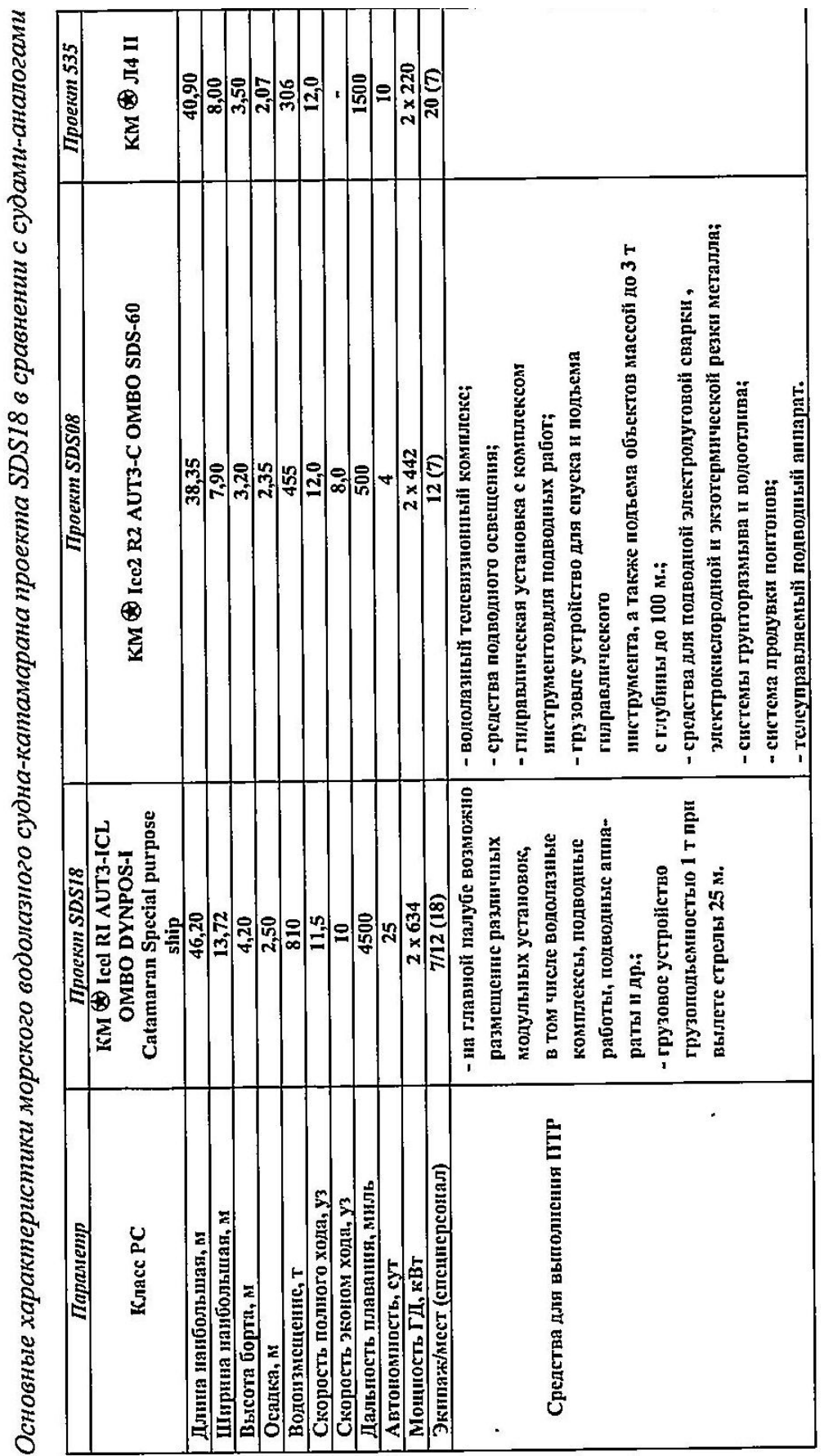




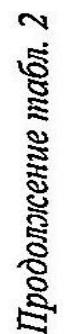

\begin{tabular}{|c|c|c|}
\hline 密 & 点 & \\
\hline 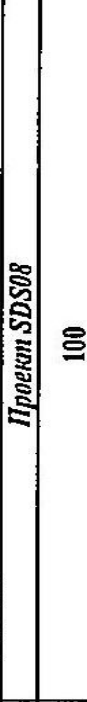 & 点 & 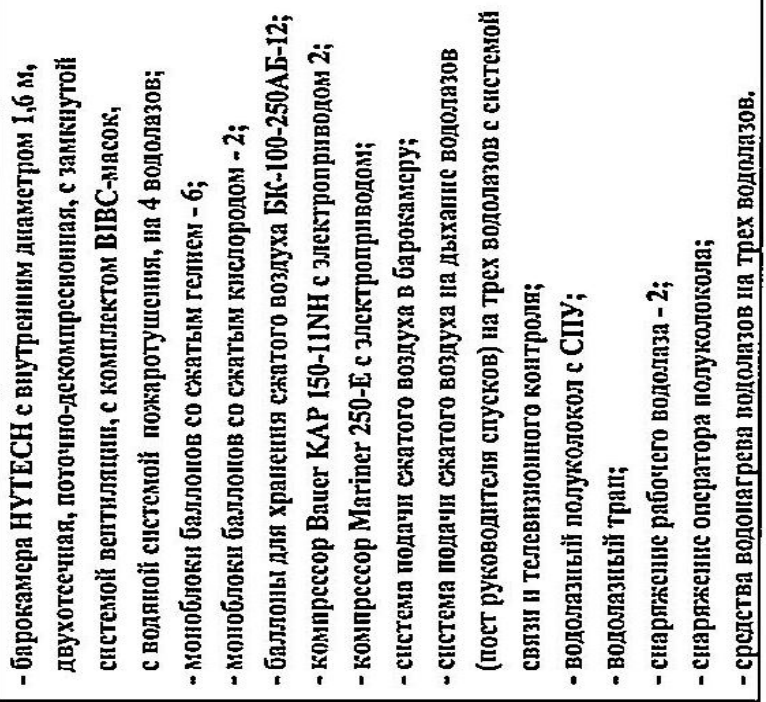 \\
\hline & 蛋 & 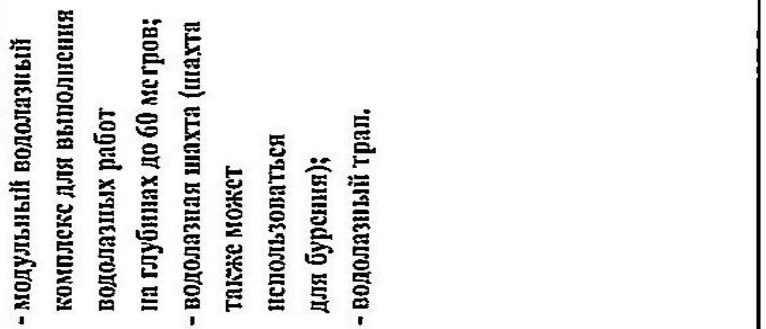 \\
\hline & 鿷 & 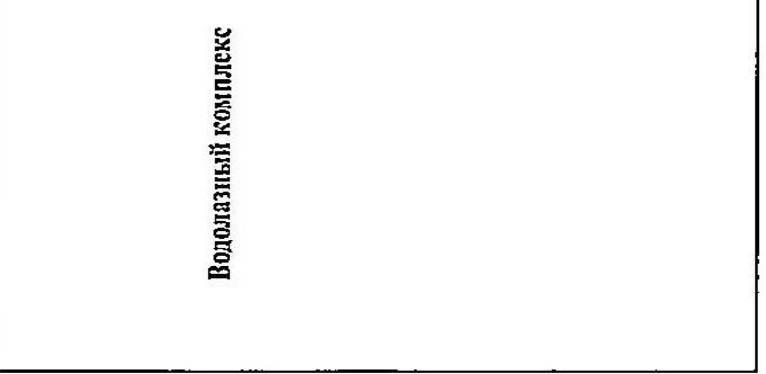 \\
\hline
\end{tabular}


ВІСНИК

ОДЕСЬКОГО НАЦІОНАЛЬНОГО МОРСЬКОГО УНІВЕРСИТЕТУ № 1 (61), 2020
HERALD

OF THE ODESSA NATIONAL

MARITIME UNIVERSITY № $1(61), 2020$
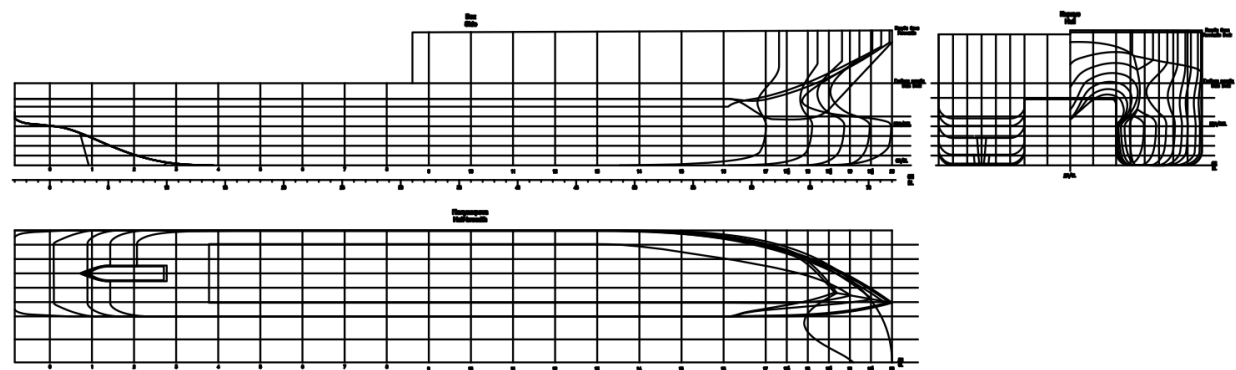

Рис. 5. Теоретический чертеж MBC проекта SDS18

При проектировании для оценки ходовых качеств судна проводились модельные испытания МВС в опытовом бассейне гравитационного типа Одесского национального морского университета (ОНМУ) имени проф. А.А. Костюкова. Применялась модель в масштабе 1:20 (см. рисунок 6).

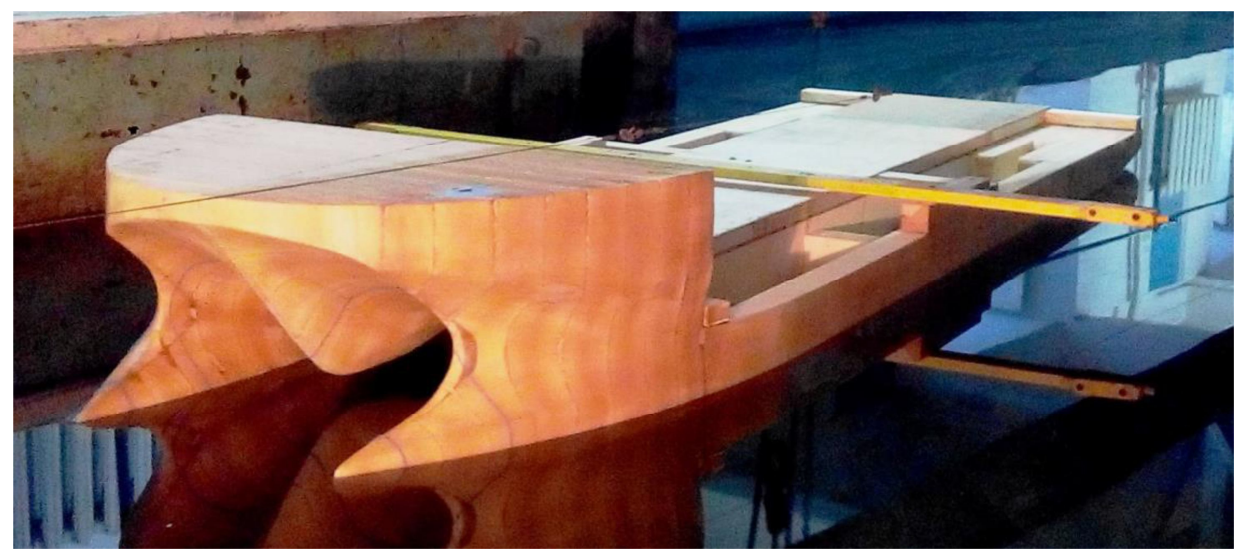

Рис. 6. Модель перед запряжкой в буксировочную систему бассейна

Результаты численных, модельных и натурных испытаний подтвердили принятые размеры судна и формой корпусов для достижения контрактной скорости 11,5 узлов при мощности пропульсивной установки $2 \times 634$ кВт и осадке 2,0 м.

Визуализация потока воды, обтекающего корпус судна при скорости 11,5 узла $(F r=0,288)$ представлена рисунке 7.

Для выполнения основных функций на судне установлено современное оборудование для выполнения водолазных и вспомогательных спасательных работ. 
ВІСНИК

ОДЕСЬКОГО НАЦІОНАЛЬНОГО

МОРСЬКОГО УНІВЕРСИТЕТУ

№ 1 (61), 2020
HERALD

OF THE ODESSA NATIONAL

MARITIME UNIVERSITY № 1 (61), 2020
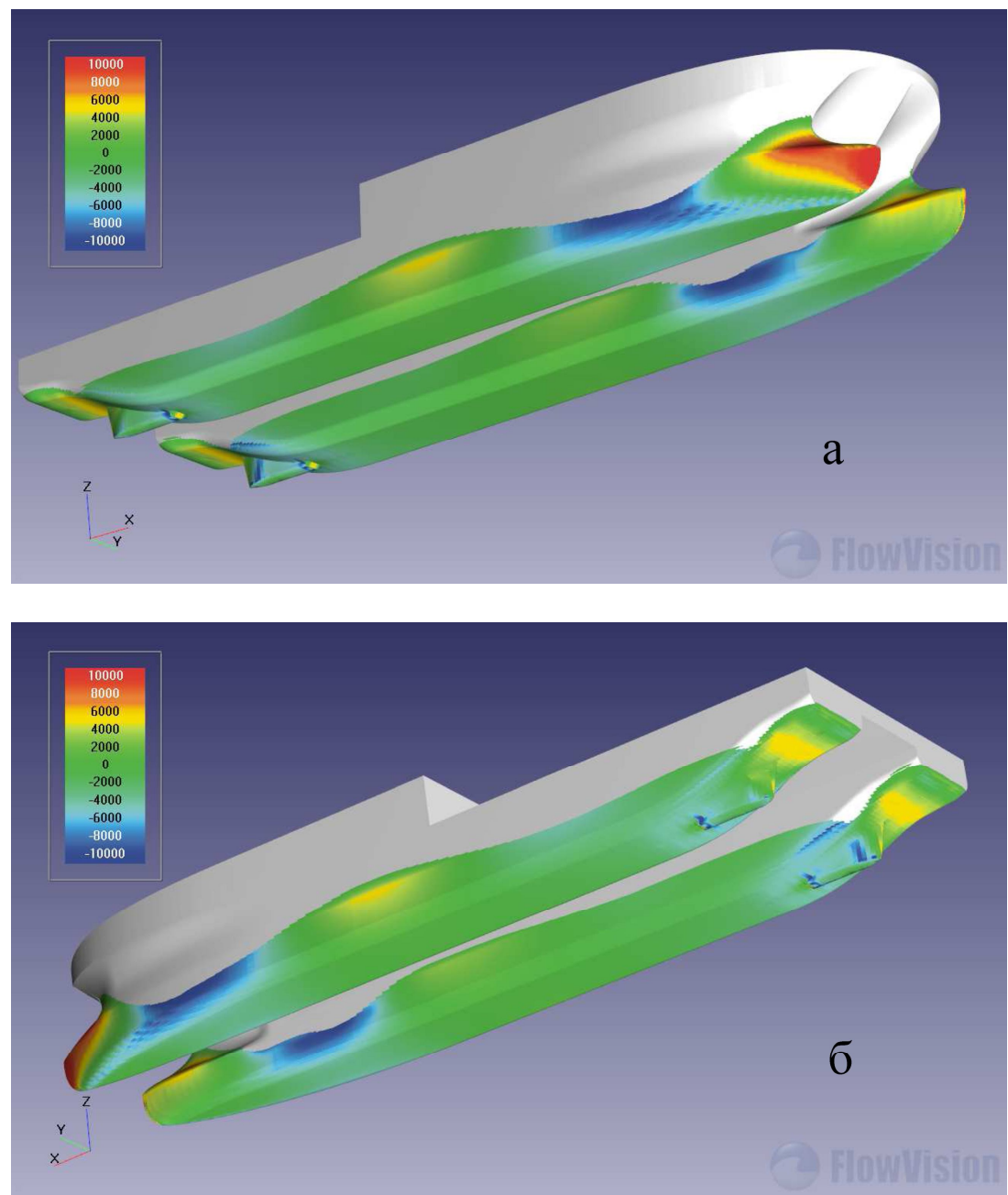

Рис. 7. Распределение давлений по результатам CFD моделирования

Особенностью концепта является наличие открытой части главной палубы площадью 250 м² (20,0 м х 13,0 м, см. рисунки 8 и 9). На палубе предусмотрено размещение водолазного комплекса для выполнения водолазных работ с использованием для дыхания сжатого воздуха на глубинах до 60 метров в мобильном контейнерном из 2 двадцатифутовых контейнеров. Для крепления контейнеров международного стандарта (TEU) на грузовой части главной палубы устанавливаются контейнерные гнёзда, а также обуха и рымы. Всего можно установить 8 двадцатифутовых контейнеров и иные модульные установки (водолазные комплексы, подводные роботы, телеуправляемые подводные аппараты и др.) максимальной массой палубного груза в 141 тонну. 
ВІСНИК

ОДЕСЬКОГО НАЩІОНАЛЬНОГО МОРСЬКОГО УНІВЕРСИТЕТУ № 1 (61), 2020
HERALD

OF THE ODESSA NATIONAL MARITIME UNIVERSITY № 1 (61), 2020

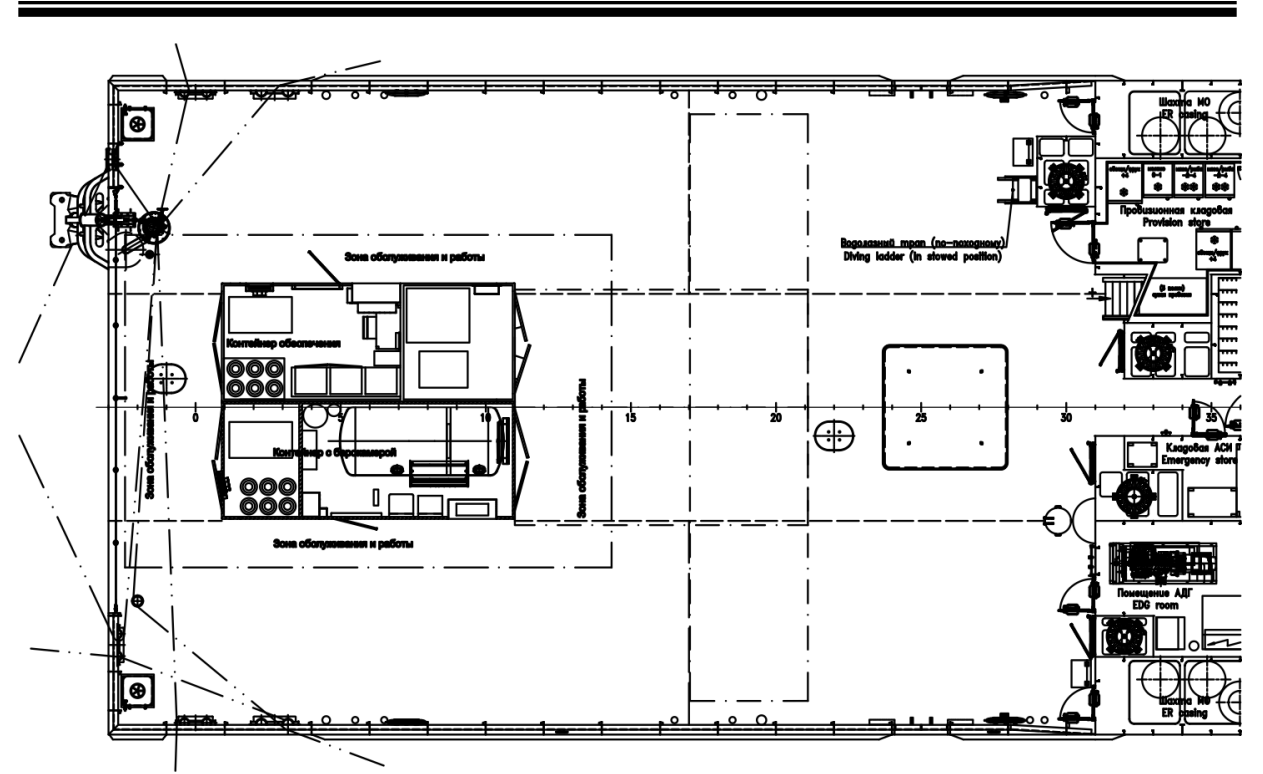

Рис. 8. Расположение модульного водолазного комплекса на главной палубе

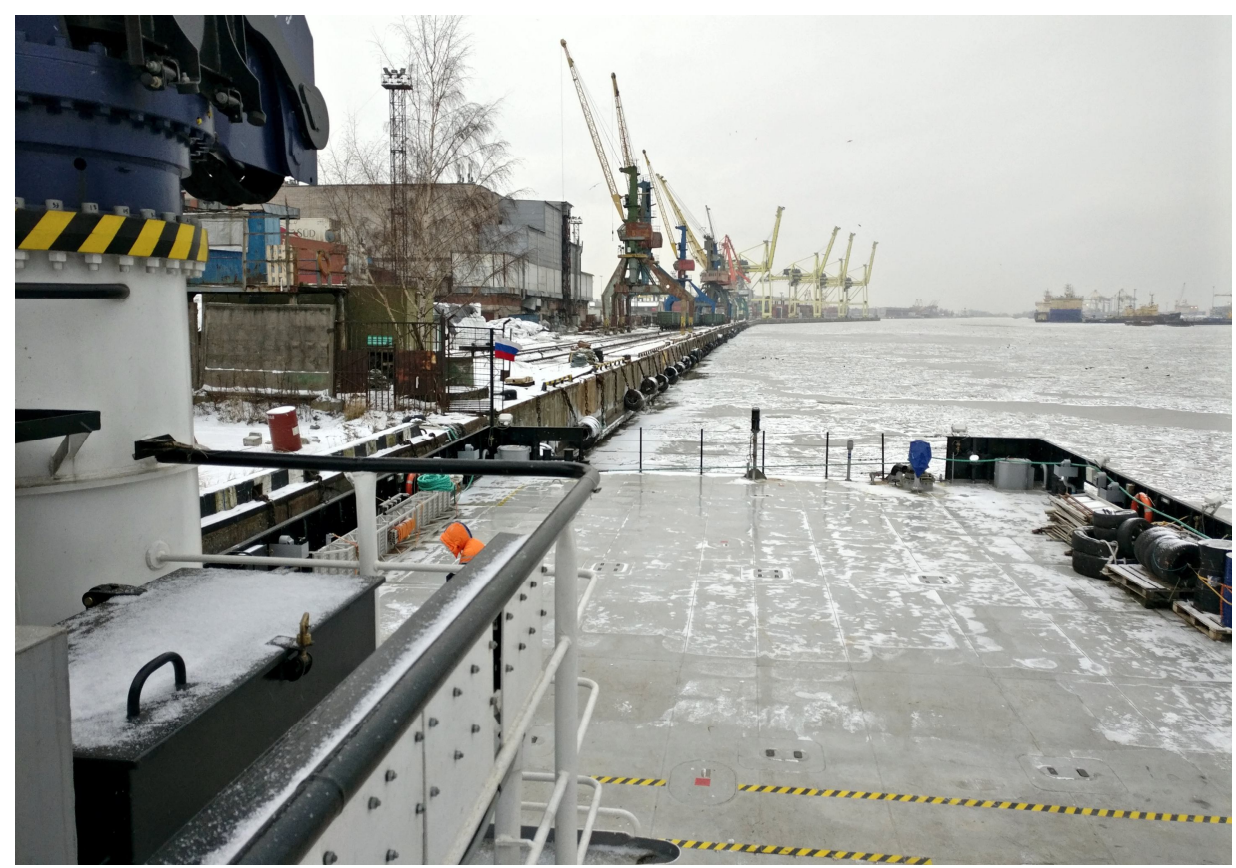

Рис. 9. Открытая часть палубы 
ВІСНИК

ОДЕСЬКОГО НАЦІОНАЛЬНОГО

МОРСЬКОГО УНІВЕРСИТЕТУ

№ 1 (61), 2020
HERALD

OF THE ODESSA NATIONAL

MARITIME UNIVERSITY № 1 (61), 2020

Для спуска водолазов на главной палубе в средней части имеется специальная шахта и водолазный трап, шахта также может использоваться для бурения и спуска под воду другого оборудования. Шахта имеет гидравлическое закрытие, которое открывается наружу вниз соединительного моста - см. рисунок 10.

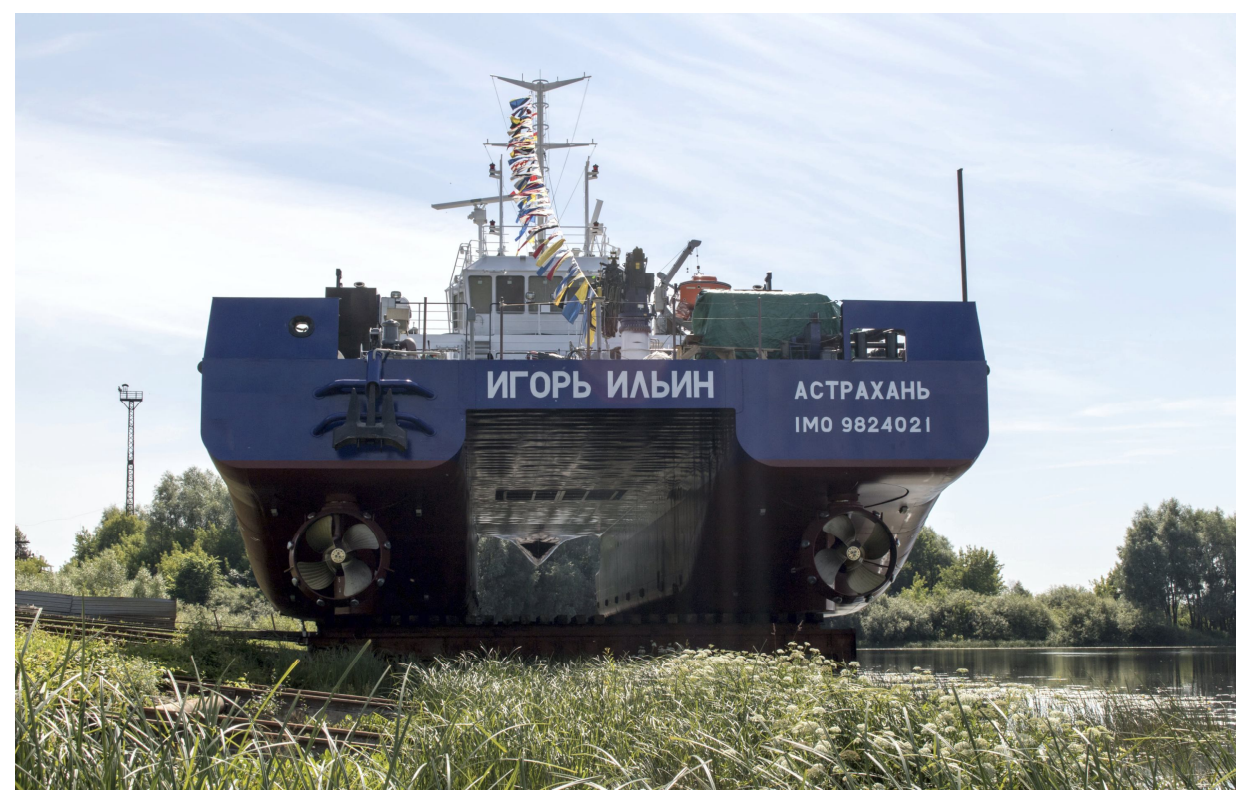

Рис. 10. Вид на корму МВС

Движение и управляемость судна обеспечивается двумя кормовыми полноповоротными ВРК с винтами фиксированного шага в насадках.

Для улучшения управляемости на малых ходах, при проходе узкостей и при швартовках и для позиционирования на судне имеется носовое ПУ типа «винт в трубе» с винтом фиксированного шага (ВФШ). ПУ каждого корпуса работают одновременно.

Водолазные и другие подводно-технические работы обеспечиваются системой динамического позиционирования DYNPOS-1. Система служит для надежного непрерывного удержания судна-катамарана относительно заданной опорной точки и следования судна в автоматическом режиме по заранее заданной траектории,

На рисунке 11 приведена диаграмма удержания судна при работе пропульсивного комплекса на $100 \%$ и осадке 2,0 м. 


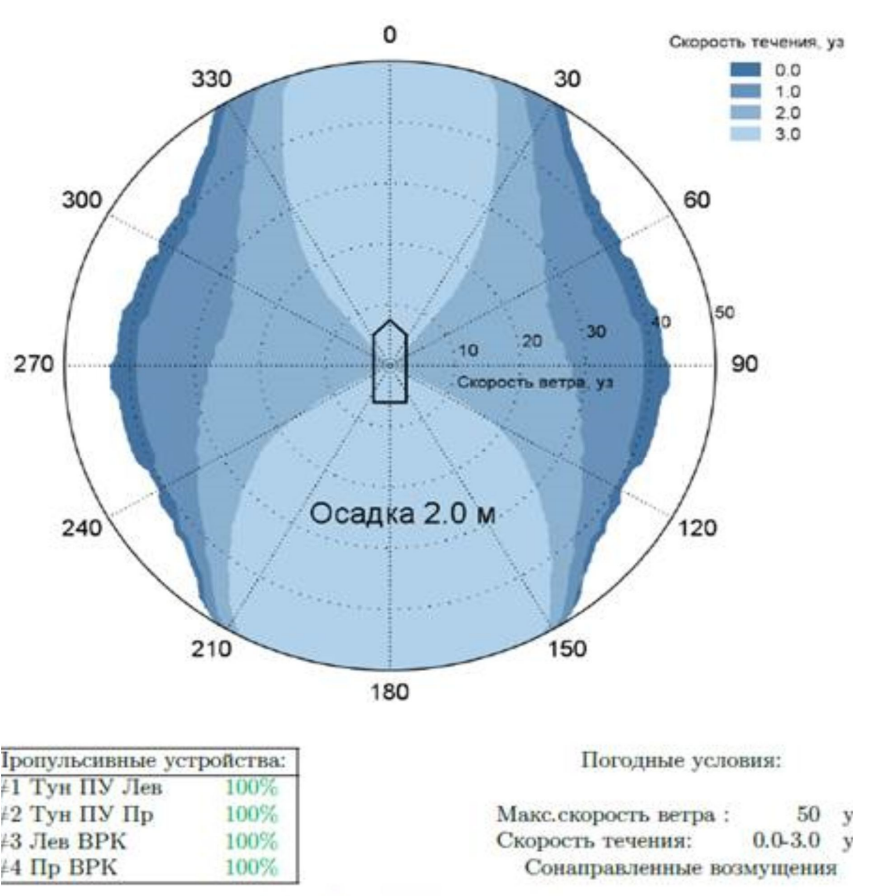

Рис. 11. Диаграмма удержания судна

Система управляет ВРК и ПУ, используя математическое моделирование маневрирования судна, что обеспечивает требуемую точность позиционирования для различных режимов работы. Управление системой динамического позиционирования осуществляется с ходового мостика.

Гидроакустическая система определения местоположения состоит из:

1. Системы позиционирования с ультракороткой базой Ranger 2 в составе:

- гидроакустический приемопередатчик тип 8142 HРТ 5000 с кабелем 30 м (см. рисунок 12);

- устройство сопряжения NSH;

- 19" дисплей;

- навигационный компьютер с программным обеспечением Ranger 2 (см. рисунок 13).

2. Транспондера для динамического позиционирования в составе: устройства обеспечения плавучести типа 870-0251 (до 3000 м) и щелочной батареи.

Для поисковых и спасательных операций судно-катамаран снабжено поисковой установкой с инфракрасной камерой, которая позволяет обнаруживать малые плавобъекты и людей на расстоянии около 7 и 2 миль соответственно. 
ВІСНИК

ОДЕСЬКОГО НАЦІОНАЛЬНОГО

МОРСЬКОГО УНІВЕРСИТЕТУ

№ 1 (61), 2020
HERALD

OF THE ODESSA NATIONAL

MARITIME UNIVERSITY № $1(61), 2020$
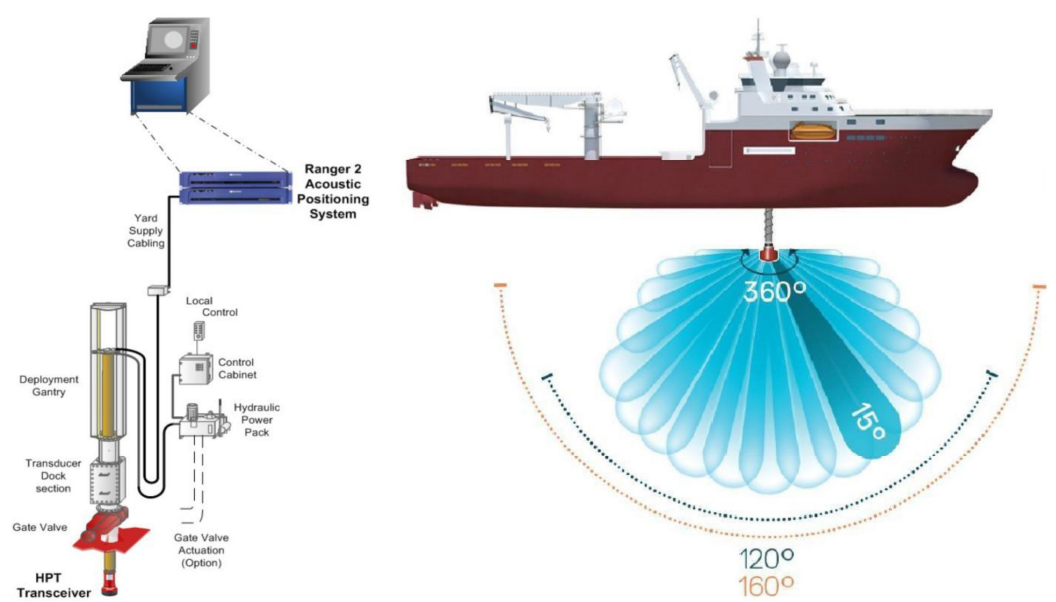

Рис. 12. Гидроакустический приемопередатчик

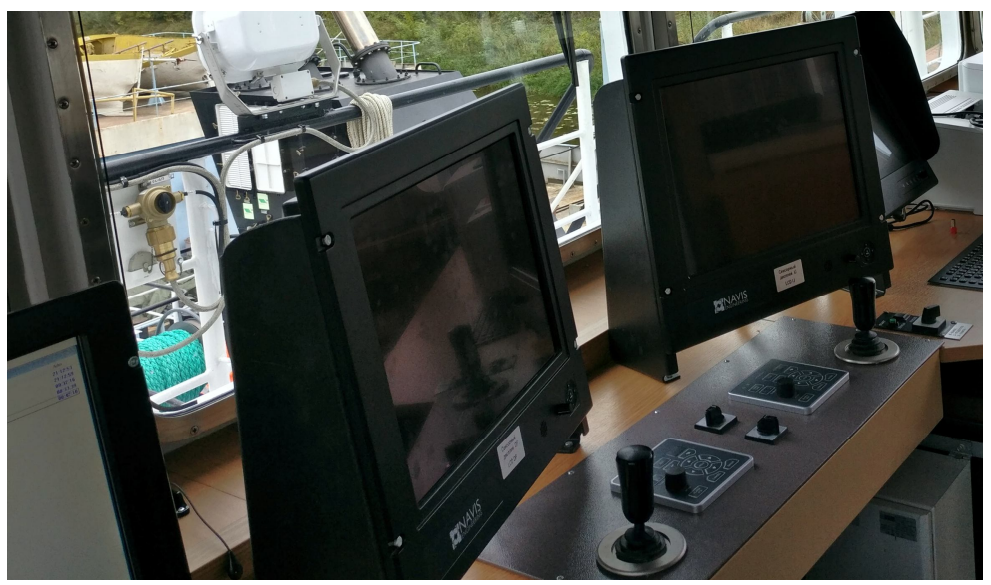

Рис. 13. Управление системой динамического позиционирования

Для работы научно-исследовательской партии предназначены две лаборатории: офис / лаборатория площадью $17 \mathrm{~m}^{2}$ на главной палубе с правого борта, и лаборатория площадью $22 \mathrm{~m}^{2}$ в правом корпусе катамарана.

Общее количество мест на судне - 31 .

Экипаж численностью 7 человек размещается в двух одноместных блок-каютах (капитан, ст. механик), состоящих из кабинета-салона, спальни и санузла и пяти одноместных кают с индивидуальными санузлами с душем. В каютах имеется по одному дополнительному спальному месту для экипажа (откидная койка второго яруса). 
ВІСНИК

ОДЕСЬКОГО НАЦІОНАЛЬНОГО

МОРСЬКОГО УНІВЕРСИТЕТУ

№ 1 (61), 2020
HERALD

OF THE ODESSA NATIONAL

MARITIME UNIVERSITY № 1 (61), 2020

Для судовладельца на палубе бака предусмотрена одноместная блок-каюта состоящая из кабинета и спальни с индивидуальным санузлом с душем.

Спецперсонал численностью 18 человек размещен на главной палубе в носовой части в девяти двухместных каютах с индивидуальными санузлами с душем.

Для экипажа и спецперсонала предусмотрена кают-компания на 16 мест на главной палубе с левого борта.

Корпуса судна (см. схему мидель-шпангоута на рисунке 14) спроектированы на ледовый класс Iсе 1. Расчетный срок службы корпуса судна 24 лет. В качестве материала основных конструкций корпуса применена судостроительная сталь категории D с пределом текучести $235 \mathrm{MПа}$ и 355 МПа. Поперечная шпация - 600 мм, шпация продольного набора 550 мм.

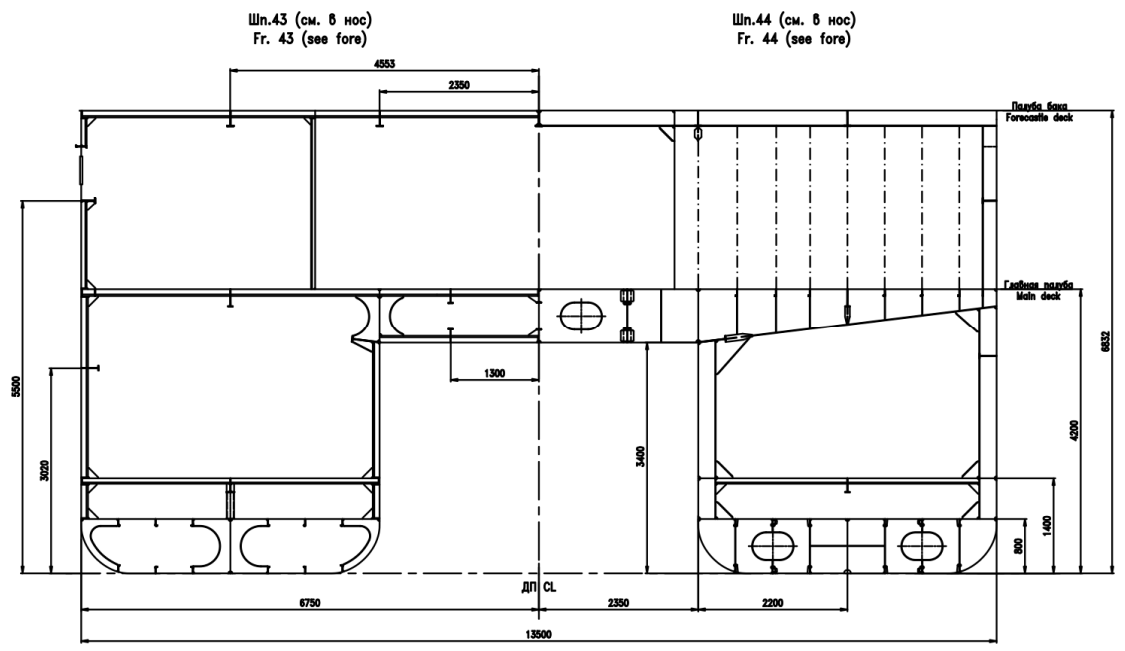

Рис. 14. Конструктивный мидель-цпангоут МBC проекта SDS18

Для выгородок в корпусе и надстройке бака - стандартные листы из стали с пределом текучести 235 МПа. Палуба ходового мостика рубки, крыша рулевой рубки, а также наружные стенки выше палубы бака и внутренние выгородки - из алюминиевого сплава АМг61 (прессованные панели).

Грузовая зона главной палубы (по длине транец -23 шп. и по всей ширине за исключением проходов у фальшбортов 965 мм) обеспечивает размещение груза с распределенной нагрузкой до 5,0 т/м².

Днище и второе дно в средней части выполнены по продольной системе набора, в оконечностях - по поперечной. Главная палуба, палуба бака, палуба ходового мостика, крыша ходового мостика, днище, борт также по поперечной системе набора. 
ВІСНИК

ОДЕСЬКОГО НАЦІОНАЛЬНОГО

МОРСЬКОГО УНІВЕРСИТЕТУ

№ 1 (61), 2020
HERALD

OF THE ODESSA NATIONAL

MARITIME UNIVERSITY № 1 (61), 2020

Соединительный мост, как главный элемент корпуса катамарана, выполнен по поперечной системе набора с усиленными рамными бимсами. Представляет собой силовую конструкцию, внутреннее пространство моста используется про проводки различных трас, труб, вентиляции, с обеспечением доступность для монтажа и осмотра во время эксплуатации.

На судне в корпусах установлены четыре главных водонепроницаемых поперечных переборки, разделяющие каждый корпус на пять непроницаемых отсеков.

Судно снабжено двумя носовыми становыми якорями повышенной держащей силы массой по 765 кг каждый и одним кормовым якорем повышенной держащей силы массой 585 кг (см. рисунок 15).

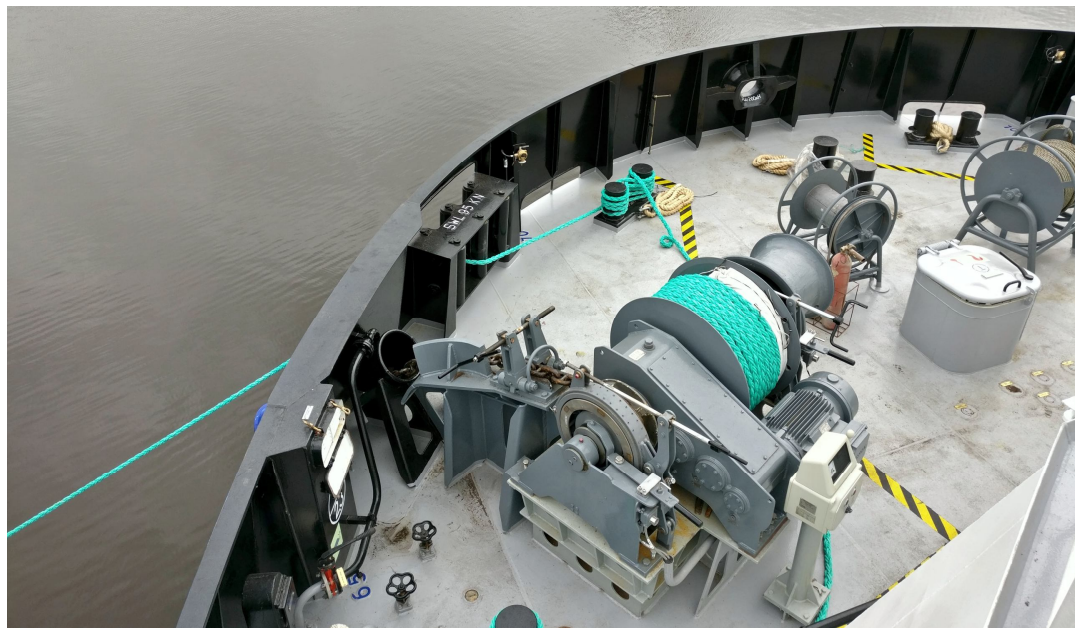

Рис. 15. Якорное устройство МВС «Игорь Ильин»

Для швартовных операций имеются якорно-швартовные лебедки в носу и якорно-швартовный шпиль в корме.

Дежурная шлюпка вместимостью 6 человек установлена на палубе ходового мостика по правому борту. Подъем и спуск шлюпки осуществляется шлюпбалкой.

Судно укомплектовано рабочим катером типа «RIB». Рабочий катер оснащен индивидуальными спасательными средствами, переносными средствами связи и переносным прожектором. На судне размещены четыре спасательных плота вместимостью 16 чел. каждый (по два с каждого борта).

На палубе бака по правому борту установлен грузовой гидравлический кран-манипулятор грузоподъёмностью 1 тона при вылете стрелы 25 м (см. рисунок 16). 
ВІСНИК

ОДЕСЬКОГО НАЦІОНАЛЬНОГО

МОРСЬКОГО УНІВЕРСИТЕТУ

№ 1 (61), 2020
HERALD

OF THE ODESSA NATIONAL

MARITIME UNIVERSITY № 1 (61), 2020

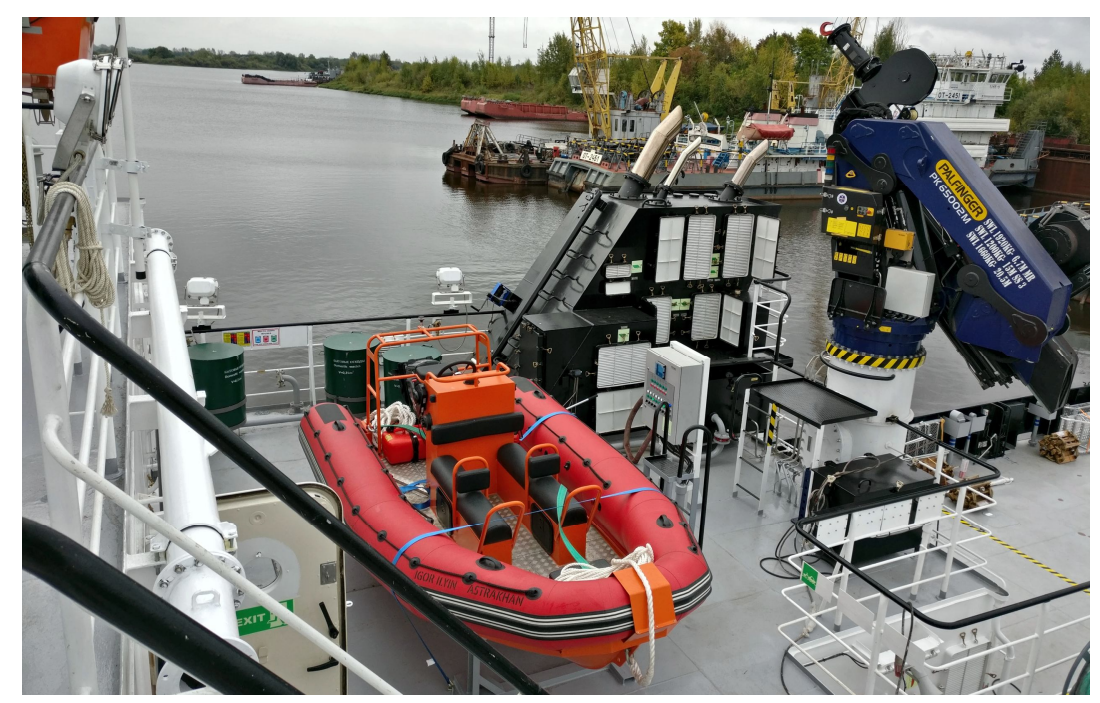

Рис. 16. Грузовой кран и рабочий катер МВС «Игорь Ильин»

Главная энергетическая установка состоит из двух дизельных двигателей максимальной длительной мощностью 634 кВт, работающих на 2 полноповоротные ВРК.

Вспомогательная энергетическая установка включает три дизельгенератора электрической мощностью 300 экВт каждый и аварийного дизель-генератора электрической мощностью около 50 экВт.

Объем и степень автоматизации технических средств судна соответствует знаку автоматизации AUT3-ICS в символе класса судна в соответствии с Правилами РС.

Практически сразу после сдачи судно приступило к работе по своему назначению.

Например, по сообщению Интерфакса, в конце 2017 - начале 2018 года многофункциональное морское водолазное судно-катамаран проекта SDS18 «Игорь Ильин» приняло участие в подготовке трассы будущего газопровода (см. рисунки 17 и 18).

Как сообщил Интерфаксу советник гендиректора НПО Специальных материалов Юрий Клёнов, уничтожение морских боеприпасов периода Великой Отечественной войны, обнаруженных на трассе будущего газопровода, впервые ведется с помощью инновационной технологии «АКВАЩИТ».

Работы обеспечивал судно-катамаран проекта SDS18 «Игорь Ильин». 


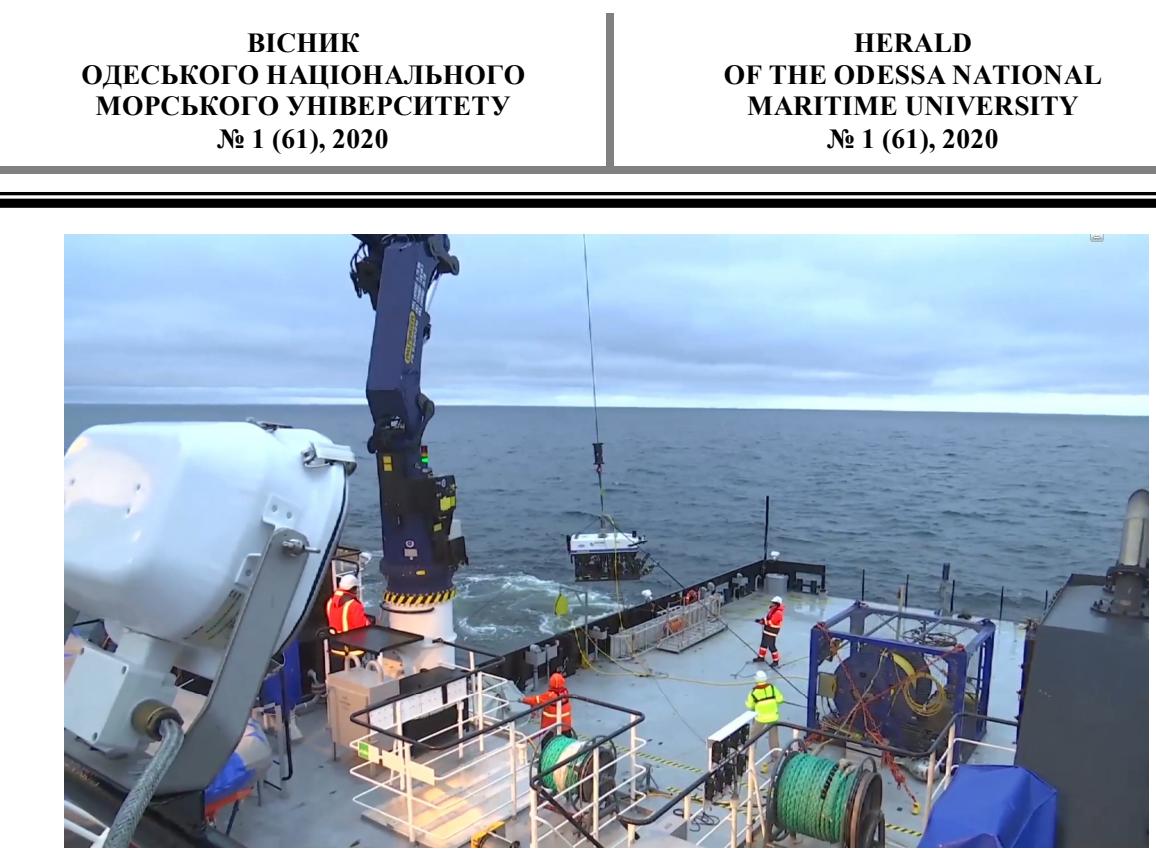

Рис. 17. МВС «Игорь Ильин» производит спуск подводного робота [5]

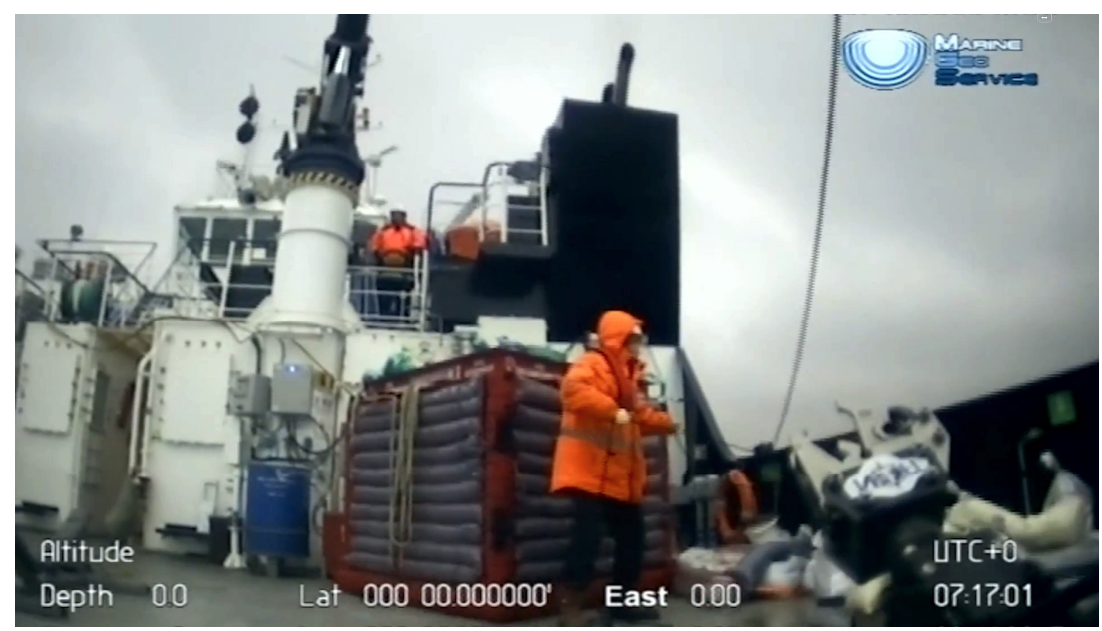

Рис. 18. Вид с подводного робота на МВС «Игорь Ильин» [5]

«Применение технологии «АКВАЩИТ» обеспечило надежную защиту ихтиофауны от фугасного воздействия при уничтожении взрывоопасных предметов», - сказал Ю. Клёнов.

Он отметил, что практическое применение технологии «АКВАЩИТ», разработанной НПО СМ и Инженерно-техническим центром Специальных работ под руководством члена-корреспондента РАН, доктора технических наук, профессора Михаила Сильникова имеет большое будущее, так как обеспечивают минимальное негативное воздействие на окружающую среду и недопущение гибели морских обитателей. 
ВІСНИК

ОДЕСЬКОГО НАЦІОНАЛЬНОГО

МОРСЬКОГО УНІВЕРСИТЕТУ

№ 1 (61), 2020
HERALD

OF THE ODESSA NATIONAL

MARITIME UNIVERSITY № 1 (61), 2020

Заключение. Создан современный проект SDS18 многофункционального водолазного судна-катамарана, характеристики которого были подтверждены эксплуатацией.

В таблице 2 приведено сравнение основных характеристик морского водолазного судна проекта SDS18 с судами-аналогами. Сочетание установленной на судне техники, возможность смены мобильного оборудования в контейнерном исполнении, большая открытая палуба, а также мощная энергетическая установка с полноповортными ВРК и динамическое позиционирование, позволяют судну решать практически любые специализированные задачи, связанные с подводно-техническими работами на глубинах до 60 м (см. рисунок 19) и выгодно отличают от практически всех судов-аналогов.

7 декабря 2017 года проект SDS18 многофункционального морского водолазного судна-катамарана «Игорь Ильин» был признан лучшим инновационным решением в сфере транспортной техники в конкурсе «Формула движения» по применению инновационных технологий среди предприятий транспортной отрасли.

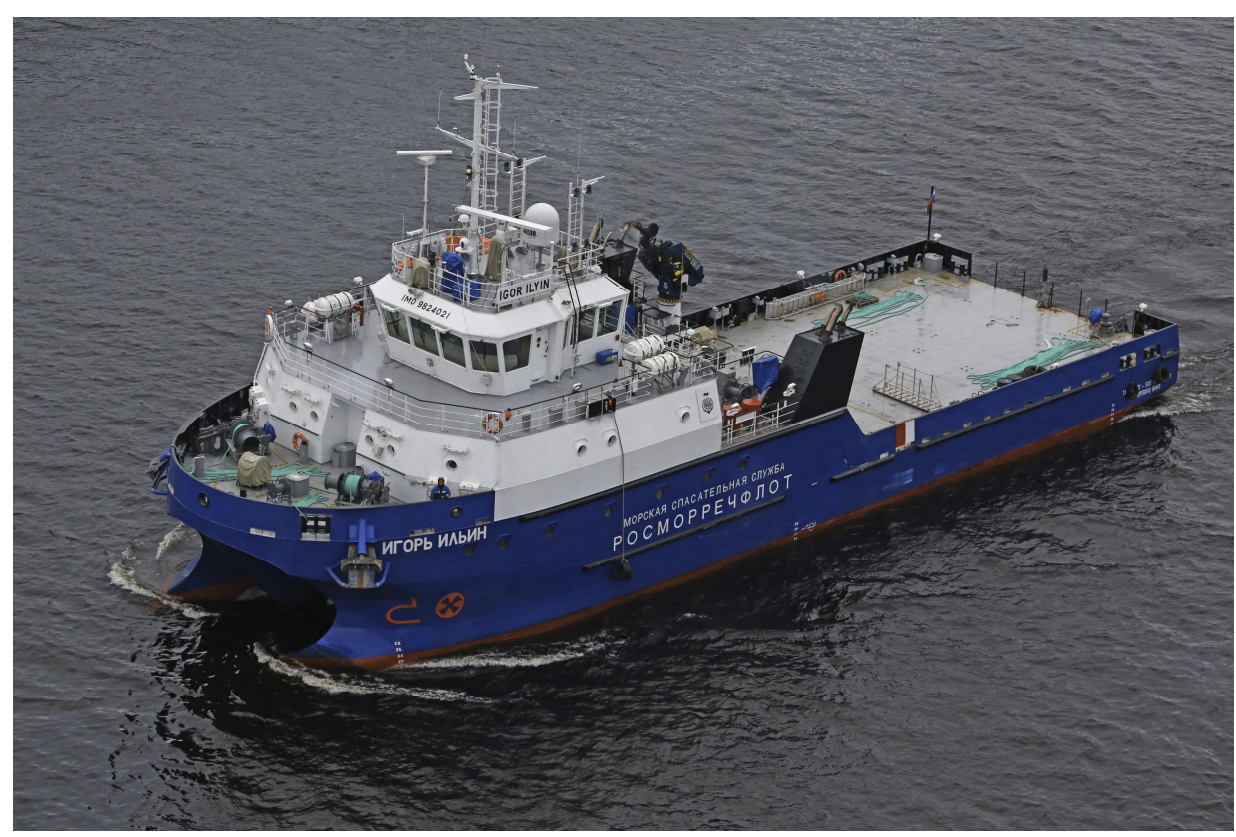

Рис. 19. Головное судно серии проекта SDS18 «Игорь Ильин»

Автор фотографии Иван Бородулин 


\section{СПИСОК ЛІТЕРАТУРИ}

1. Воеводская Е.Н. Оиенка ходовых качеств катамаранного судна. Судостроение. 1964. №7. С. 6-9.

2. Былинович Е.С. Особенности проектирования НИС-катамаранов для сейсмических исследований // Труды Крыловского государственного научного иентра. 2012. Bыn. 70 (354). C. 171-196.

3. Фотогалерея «Многофункииональное морское водолазное судно-катамаран «Игорь Ильин» проекта SDS18» // Фотография "Строительство головного судна проекта SDS18». http://www.korabli.eu/images/oboi/grazhdanskie-suda/proekt-sds

18/ full/stroitelstvo-golovnogo-sudna.jpg). Дата обращения 10.03.2020.

4. Сайт Морской Спасательной службы РФ // Раздел «Водолазные cyda». http://morspas.com/flot/vodolaznye-suda. Дата обращения 10.03.2020.

5. Видео-канал «ИНЦИДЕНТ». Разминирование боеприпасов под водой // YouTube. 01.12.2017. Кадры из видео https:// www. youtube.com/watch? $v=C 7 A D y n d I 5 r 4$. Дата обращения 10.03.2020.

6. Тесленко А.П. Реализация программы строительства спасательного флота для Госморспасслужбы России // Нептун. 2011. № 4. C. 26-31.

7. Обоснование параметрического ряда многофункииональных судов-спасателей гражданского назначения / Г.В. Егоров, И.А. Ильниикий, В.И. Тонюк, Н.В. Автутов // Вестник ОНМУ. Oдесса: OHMУ, 2013. Bыn. 3 (39). C. 5-36.

\section{REFERENCES}

1. Voevodskaya E.N. (1964). Otsenka khodovykh kachestv katamarannogo sudna [Estimation of running characteristics of catamaran type ship]. Sudostroenie journal (Shipbuilding journal), 7, 6-9 [in Russian].

2. Bulinovich E.S. (2012). Osobennosti proyektirovaniya NIS-katamaranov dlya seysmicheskikh issledovaniy [Design features of scientific and research catamarans for seismic investigations]. Trudy Krylovskogo gosudarstvennogo nauchnogo tsentra (Proceedings of Krylov state research center), 70 (354), 171-196 [in Russian]. 
3. «Korabli.Eu» website // SDS18 diving ship-catamaran photo. Retrieved from: http://www.korabli.eu/images/oboi/grazhdanskiesuda/proekt-sds18/full/stroitelstvo-golovnogo-sudna.jpg (access date 10.03.2020).

4. «Morspassluzhba» website. Retrieved from: http://morspas. com/ flot/vodolaznye-suda (access date 10.03.2020).

5. "Incident" YouTube video-canal // Frame from video. Retrieved from: https://www.youtube.com/watch? $v=C 7$ ADyndI5r4 (access date 10.03.2020).

6. Teslenko A.P. (2011). Realizatsiya programmy stroitel'stva spasatel'nogo flota dlya Gosmorspassluzhby Rossii [Realization of program of building of salvage fleet for Russian State Rescue Service]. Neptune journal, 4, 26-31 [in Russian].

7. Egorov G.V., Ilnytskiy I.A., Tonyuk V.I., Avtutov N.V. (2013). Obosnovaniye parametricheskogo ryada mnogofunktsional'nykh sudov - spasateley grazhdanskogo naznacheniya [Justification of parametric lineup of multifunctional vessels-rescuers of civil assignment]. Visnuk ONMU (Herald of Odessa National Maritime University), 3 (39), 5-36 [in Russian].

Стаття надійшла до редакиії 24.01.20

Посилання на статтю: Егоров Г.В., Черников Д.В. Особенности проектирования многофункционального водолазного судна-катамарана проекта SDS18 типа «Игорь Ильин» // Вісник Одеського національного морського університету: 3б. наук. праць, 2020. № 1(61). C. 7-28. DOI 10.47049/2226-1893-2020-1-7-28.

Article received 24.01.20

Reference a JournalArtic: Yegorov, G., Chernikov, D. (2020). Design features of SDS18 multifunctional diving vessel-catamaran of «Igor Ilyin» type. 1(61), 7-28 // Herald of the Odessa national maritime university. DOI 10.47049/2226-18932020-1-7-28. 